\title{
CRYPTOSPORIDIOSIS AMONG PATIENTS WITH ACQUIRED IMMUNODEFICIENCY SYNDROME (AIDS) IN THE COUNTY OF SÃO PAULO, BRAZIL
}

\author{
Rosa Maria Donini Souza DIAS (1), Ana Célia Steffen MANGINI (1), \\ Domingas Maria A. Grispino Vieira TORRES (1), Marcelo Oswaldo A. CORRÊA (1), Norival LUPETTI (1), \\ Fernando M. A. CORRÊ (2) \& Pedro Paulo ChIEFFi (1)
}

\begin{abstract}
Stool samples of 157 patients with AIDS, living in the county of São Paulo, were submitted to several techniques in the search for Cryptosporidium sp.. Among the various techniques tested for slide preparation (direct smear, spontaneous sedimen tation method, and formol-ether concentration). the latter, formol-ether concentration, offered the best results, clearly outdoing all the others. Nineteen samples out of 157 prepared by this technique, after dyeing by the Kinyoun method or by carbol fuchsin dimethyl sulfoxide, were found to be positive for Cryptosporidium sp..
\end{abstract}

KEY WORDS: Cryptosporidium sp.; Cryptosporidiosis: AIDS.

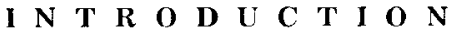

Cryptosporidium sp. was first described by TIZZER, in 1907, who observed this coccidium in the gastric mucosa of asymptomatic mice. SLAVIN, in 1955, associated it to severe disease, when noticed its presence in turkeys with acute diarrhea ${ }^{13}$. Since that time, several publications mention the finding of Cryptosporidium sp. in different animal species, with varied clinical pic tures ${ }^{5.14}$.

Since 1976, when the first human case of cryptosporidiosis was described, no more than seven cases had been reported in the literature until $1982^{11}$

With the emergence of AIDS. Cryptosporidium sp. came to be frequently considered as the etiologic agent of prolonged and difficult to treat diarrhea in immunocompromised patients ${ }^{11}$. More recently, this coccidium has been incriminated as the causative agent of severe diarrhea, usually auto-limited, in immunocompetent individuals ${ }^{4.10}$, particularly among groups exposed to infected animals ${ }^{12}$

In Brazil, the presence of Cryptosporidium $\mathrm{sp}$. oocysts has been observed in the stool of patients with diarrhea episodes, with or without concomitant immunosuppressant process ${ }^{2.3 .8 .15}$. Nevertheless, reports on the frequency of Cryptosporidium sp. isolation on the stools of individuals with AIDS are scarce and this was the main goal of the present study.

\footnotetext{
(1) From Instituto Adolf Lutz, Sào Paulo, Brazil

(2) From Instituto Butantan. Sāo Paulo, Brazil

Address for correspondence: Dra Rosa Maria D Souza Dias. Instituto Adolfo Lutz. Seçáo de Enteroparasitoses Av Dr Arnaldo. 355. CEP 01246 Sào Paulo. SP. Brazil
} 
DIAS, R. M. D. S.: MANGINI, A. C. S.: TORRES. D. M. A. G. V.: CORREA. M. O. A.; LUPETTI, N., CORREA, F.

M. A. \& CHIEFFI, P. P. - Cryptosporidiosis among patients with acquired immunodeficiency syndrome (AIDS) in the county of São Paulo, Brazil. Rev. Inst. Med. trop. Sáo Paulo, 30 (4): 310-312, 1988.

\section{MATERIALS AND METHODS}

The presence of Cryptosporidium sp. oo cysts in diarrheic stool samples was studied. Such sample came from 157 AIDS patients, refer red to the Enteroparasitosis Section of Adolfo Lutz Institute, from June to April 1987

Aiming the testing of different methods for concentration and dyeing of Cryptosporidium sp. oocysts, the stool samples were submitted to various examination techniques. Direct stool smears, spontaneous sedimentation method (Lutz method), and formol-ether concentration were thus used. Sample staining techniques em ployed were lugol staining, Giemsa dye, carbol fuchsin dimethyl sulfoxide, and Kinyoun method.

All such techniques followed precepts stated in the literature ${ }^{1.6 .9}$, exception made for the for mol-ether concentration which was slightly modified. For this technique, stool fractions were ho mogenized in $4 \mathrm{ml}$ of $10 \%$ formaldehyde solution, pH $7.0 ; 2 \mathrm{ml}$ of ethyl ether were added to the resulting solution, after gauze filtering and transference to a centrifugation test tube. After sealing with a rubber stopper, the test tube was stirred and submitted to centrifugation at 1,500 rpm for 5 minutes. The supernatant was discarded, smears were made on glass slides from the sediment which. after being dried and methanol fixed, were stained.

\section{RESULTS}

Cryptosporidium sp. oocysts were found through the modified formol-ether concentration method in $19(12.1 \%)$ samples collected from 157 AIDS patients and submitted to several examination techniques.

Both the sedimentation and direct smear methods proved unable to demonstrate the pre sence of Cryptosporidium sp. on samples where formolether concentration method succeeded in demonstrating oocysts of the coccidium as. only in one case out of the 19 positive, such oocysts were elicited through those techniques.

\section{DISCUSSION}

The study of the frequency of opportunistic infections in AIDS patients secured great rele- vance due to the growing number of the disease in the recent years. Therefore, research on safe, reproducible, and easy to perform techniques for the etiologic diagnosis of the many infections often associated to the nosologic picture of AIDS attains marked importance, since diagnosis and treatment of such infections are the only forms, presently known, to extent and improve life qua lity of these patients. Similarly, studies which seek to determine occurence rates of the several agents implicated on the etiology of secondary infections in AIDS patients are justified

Cryptosporidiosis, particularly in its intesti nal form, is one of the most frequent opportu nistic infections affecting AIDS patients ${ }^{5}{ }^{14}$. Ne vertheless, data are scarce on the affliction of AIDS patients by Cryptosporidium sp. in our country. According to COURA ${ }^{3}$, in the only Bra zilian research involving a large number of patients, conducted in the county of Rio de Janeiro, oocysts of this coccidium were found in approxi mately $17 \%$ of AIDS patients with prolonged diarrhea.

Findings of this study, at a first glance, point to a lesser Cryptosporidium infection frequency among AIDS patients living in the county of São Paulo, on account of showing oocysts in no more than $12.1 \%$ of the stool samples examined. Ne vertheless, it must be emphasized that differen tly from patients examined in Rio de Janeiro, not all São Paulo patients were diarrheic. Work recently performed in Zaire ${ }^{7}$, on AIDS suspected individuals with diarrhea episodes revealed $8 \%$ Cryptosporidium sp. infection rate.

It is still valuable to underscore the importance of using the formolether concentration technique, slightly modified from the GARCIA \& col ${ }^{6}$ method, before preparing the fecal smear to be stained. Stool samples prepared under dif. ferent techniques - direct smear or spontaneous sedimentation - yielded results always less ex pressive than those of formolether concentration method, denoting this to be the method of choice for isolation of Cryptosporidium sp. oo cysts.

\section{RESUMO}

Criptosporidiose em pacientes acometidos pela síndrome de imunodeficiècia adquirida (AIDS), no município de São Paulo, Brasil 
DIAS, R. M. D. S.; MANGINI, A. C. S.: TORRES, D. M. A. G. V.; CORREA, M. O. A.; LUPETTI, N.; CORREA, F. M. A. \& CHIEFFI, P. P. - Cryptosporidiosis among patients with acquired immunodeficiency syndrome (AIDS) in the county of São Paulo, Brazil. Rev. Inst. Med. trop. São Paulo, 30 (4): 310-312, 1988.

Amostras de fezes de 157 pacientes acome tidos pela síndrome de imunodeficiencia adqui rida, residentes no município de São Paulo, foram submetidas a diversas técnicas para pesquisa de Cryptosporidium sp.. Entre as diversas técnicas testadas para o preparo das lâminas (esfregaço direto, método de sedimentaçāo espon tânea e concen tração pelo formol-éter) a concentraçāo pelo formol-éter foi a que forneceu melhores resultados, superando nitidamente as de mais. Nas 157 amostras preparadas por esta téc nica, após coloração pelo método de Kinyoun ou pela fucsinacarbólica dimetilsulfóxido, encontraram-se $19(12,1 \%)$ positivas para oocistos de Cryptosporidium sp..

\section{REFERENNCIAS BIBLIOGRAFICAS}

1. BRONSDON, M. A. - Rapid dimethylsulfoxide modified acid-fast stain of Crystosporidium oocysts in stool specimens. J. clin. Microbiol., 19: 952 953, 1984.

2. COELHO, K. I. R.; MAEDA, S. \& MARQUES, M. E. A - Intestinal cryptosporidiosis. Association with Pneumocystis carinii, cytomegalovirus and Candida sp. infec tions. Rev. Inst. Med. trop. S. Paulo, 29: 323-326, 1987.

3. COURA, J. R. - Parasitoses nos portadores de AIDS. J. bras. Med., 53: 42-54, 1987.

4. CURRENT, W. L.; REESE, N. C.: ERNST, J. V.; BAILEY, W. S.; HEYMAN, M. B. \& WEINSTEIN, W. H. - Human cryptosporidiosis in immunocompetent and immunode ficient persons. New Engl. J. Med., 308: 1252 1257, 1983

5. FAYER, R. \& UNGAR, B. L. P.-- Cryptosporidium spp and cryptosporidiosis. Microbiol. Rev., 50: 458 483, 1986.
6. GARCIA. L. S.: BRUCKNER, D. A.: BREWER, T. C. \& SHIMIZU, R. Y. - Techniques for the recovery and identi fication of Cryptosporidium oocysts from stool speci mens. J. clin. Microbiol., 18: 185-190, 1983

7. HENRY, M. C ; DE CLERCQ, D : LOKOMBE, B. KAYEMBE, K : KAPITA, B : MAMBA, K ; MBENDI, N \& MAZEBO, P. -- Parasitological observations of chronic diarrhoea in suspected AIDS adult patients in Kinshasa (Zaire). Trans. roy. Soc. trop. Med. Hyg., 80: 309.310, 1986

8. LOUREiRo, E. C. B.: LiNhares. A. C. \& MATA. L. Acute diarrhoea associated with Cryptosporidium sp. in Belém, Brazil. (Preliminary report). Rev. Inst. Med. trop. S. Paulo, 28: $138-140,1986$

9. MA, P. \& SOAVE, R. - Three step stool examination for cryptosporidiosis in 10 homosexual men with protacted watery diarrhea. J. infect. Dis, 147: $824828,1983$.

10. MATA, L.: BOLAÑOS, H: PIZARRO, D. \& VIVES, $M$ - Cryptosporidiosis in children from some highlands Cos ta $\mathrm{Rican}$ rural and urban areas. Amer. J. trop. Med. Hyg., 33: 24-29, 1984 .

11. NAVIN, T. R, \& JURANEK, D. D. - Cryptosporidiosis: clinical, epidemiologic, and parasitologic review. Rev. infect. Dis., 6: $313 \cdot 327,1984$.

12. POLIJOLA, S.; OKSANEN, H.; JOKIPII, L. \& JOKIPII A. M. M. - Outbreak of cryptosporidiosis among veteri nary students. Scand. J. infect. Dis., 18: 173.178, 1986

13. SLAVIN, D. - Cryptosporidium meleagridis (sp. nov.) J. comp. Path., 65: 262-266, 1955.

14. TZIPORI, S. - Cryptosporidium: notes on epidemiology and pathogenesis Parasit. today, 1: 159.165, 1985

15. WEIKEL, C. S; JONHSTON, L. I; SOUZA, M. A. \& GUERRANT, R. C. - Cryptosporidiosis in northeastern Brazil: association with sporadic diarrhea. J. infect. Dis., 151: $963.965,1985$.

Recebido para publicaçáo em 22/3/1988 